Imagining the Urban Poland: Revolution and Reconceptualization of Urban Society in the Kingdom of Poland, 1905-1914

The aim of this article is to analyze how the concept of mieszczaństwo was redefined in Polish political discourse between 1905 and 1914 in conjunction with concepts of intelligentsia and bourgeoisie. My hypothesis is that before the Great War, in a time of powerful social and political revolutions that took place on the streets of Warsaw, Łódź and other cities, new ways of conceptualizing the urban society emerged. I shall discuss the circumstances that led to the forming of the concept of the Polish mieszczanstwo during the debate about the urban self-government in the Kingdom of Poland after the 1905 Revolution.

As the city itself became the subject of political competition, and the right to govern the city became a demand of the Polish public opinion. For National Democratic Party it was an excellent occasion to expand anti-Semitic rhetoric and promote the idea of the Polonization of cities as a long-term goal. However, I argue that this rhetoric would not find public response if the intelligentsia itself would not redefined its attitude to other groups of urban dwellers. The mieszczaństwo, which had no political meaning previously, became the main factor of the imagined modernization of Poland. Despite the price of the ethnic conflict it became obvious that Poland had to be urbanized to be modernized.

Keywords: antisemitism, intelligentsia, Łódź, mieszczaństwo (burghers), modernization, urban society, Warsaw 
At the beginning of the twentieth century Tsarist Russia experienced many events that could be called "revolutionary." Although the proletarian revolution of 1905 was the most important and the best recognized of them, it had been preceded by profound changes in social structure and mass communication. Historiography is generally convinced that late imperial Russian was the place where some kind of "urban revolution" took place (Brower 1986). The growing importance of cities itself and meshchanstvo, "the lowest order of the urban population," or-in different words-"indigenous urban stratum" (Koshman 2016, 97), prepared a ground for modernization and political change.

The Kingdom of Poland, the western frontier of the Empire, played an important role in this process. What should be stressed here is, Russian Poland was, together with the Pale of Settlement-the huge area of the former Polish-Lithuanian Commonwealth (modern Lithuania, Belarus and Ukraine), where Jews were allowed to settle after the 1880s. Liliana Riga argued that "provinces of the Jewish Pale constituted a sensitive geopolitical frontier, triggering some of the Russian state's most repressive and Russificatory policies" $(2008,669)$. What was characteristic for this multiethnic region, the agrarian social structure went hand in hand with weakness of towns (Kochanowicz 2006, 186).

Unlike central Russia, in the Kingdom of Poland and other Western Provinces of the Russian Empire, the meshchanstvo (in Russian) or mieszczaństwo (in Polish)-the strata of urban dwellers-consisted there mostly of Jews who lived in towns. Traditional Jewish Shtetl was in fact a specific form of urban life, very far from what is used to be regarded as the predominant model of urban life (Katz 2007).

However, in the same time, Russian Poland became the most urbanized and industrialized part of the Empire, with Warsaw and Łódź as the third and fifth largest cities in 1900. Cities became an important factor of the social change and modern politics (Blobaum 1995, 18-28) but, like the whole country, they were ruled in an archaic, oppressive and undemocratic way, with the embarrassing cultural and infrastructural underdevelopment, comparing both to Europe and Russia (Śmiechowski 2014b, 75-80).

Following Ernest Gellner, I believe that concepts "are correlates of all the institutions of a society; and to understand the working of the concepts of a society is to understand its institutions" (Gellner 1970, 115). All dimensions of political language which are connected with social structures are dependent on processes and changes that happen in historical time, including urbanization and democratization of the social communication. The nineteenth century was a huge "transformation of the world," when whole regions evolved from feudal to capitalist, 
from rural to urban, and from traditional communities to modern nations. From this point of view, case of partitioned Poland in the late nineteenth and early twentieth century also should be considered in reference to broader processes of nation-building and modernization of society (Tréncsenyi et al. 2016).

As Wiktor Marzec and Risto Turunen noted, "the Revolution of 1905 played a paramount role in the mass circulation of political concepts" in East Central Europe (Marzec and Turunen 2018, 41). After the political system in Russia became liberalized, the press achieved higher social recognition. The number of legal Polish newspapers and periodicals increased from 111 before 1904 to 316 in 1907 (Kmiecik 1980, 22-4). For the first time in Poland dailies were sold on the streets. Mass demonstrations, rallies, thousands of illegal brochures changed cities in Russian Poland into a "social laboratory," where different political concepts competed for the support of the masses (Blobaum 1995; Samuś 2013). When political language moved from salons and newspapers onto the streets, the most significant internal barriers that prevented the transformation of Polish political language into a modern tool of social communication disappeared. Consequently, it can be stated that the foundations for the modern Polish public sphere were established in the Kingdom of Poland as an aftermath of the 1905 Revolution (Marzec and Śmiechowski 2016).

What interests me here is the reconceptualization of relations between strata of urban society that determine shape of modernity in Polish political language after the 1905 Revolution. What is necessary to stress here is that the Polish word "mieszczanstwo" is similar to English "burghers"-a city dwellers, and means just all people living in the city. Thus, it has a different meaning than burżuazja, which in Polish often referred only to the economic elites of urban society, the "upper bourgeoisie." Adam Kożuchowski, who tried to define the difference between burżuazja and mieszczaństwo in Polish, argued:

In short, the difference between burżuazja and mieszczanstwo is that the former were having fun, blithely and brazenly-they overtly worshipped profit and success, were never embarrassed about it and did not even care about their hypocrisy. (...) Mieszczaństwo has stayed a more convenient construction: timid by definition, embarrassable, disrespectable and snubbable-hardly a rival for the status of the social elite. (Kożuchowski 2020, 92)

This situation muds the waters when comparing Russian Poland with the West, certainly. Nonetheless, this ambiguity is quite typical for Russia 
and other Eastern European societies, where "burghers, mainly small merchants and craftsmen, were a dispersed provincial class with mediocre aspirations" (Jedlicki 2009, 21). As Robert Blobaum noted, the political discourse of the time, freed from pre-revolutionary restrictions, was a place where Polish path to modernity was trodden (Blobaum 1995, 188-233).

The questions about the role of the intelligentsia and mieszczanstwo in the future urban society were answered in a different way depending on who and where was formulating the answers. Following this line of thought, I am interested how concept of the mieszczaństwo was used in the public discourse created by the Polish intelligentsia between the 1905 Revolution and the Great War.

Transformation of the Intelligentsia: From Social Sphere to Political Concept

What is clear, the intelligentsia itself is considered to be one of the overarching concepts in modern Eastern European history (Sdvizkov 2006). This term appeared in Polish in the mid-1840s and replaced an older term, "intellectual class" (in Polish: "klasa umystowa") (Walicki 2005, 3; Jedlicki 2009, 17). In the 1860s, the term spread from Central Europe and became common in Russia (Pipes 1960, 488). The concept of the intelligentsia evolved and crystallized over time and finally became commonly understood as "the class consisting of educated people."

By 1900 this definition, linking the level of education with being a member of this social group became a default one. For instance, Ludzkośc (Humanity), the leading liberal journal from Warsaw, described the intelligentsia in the following way: "scientists, doctors, attorneys, teachers, authors, artists"-this is category of the favored intelligentsia where ideas are blossoming and culture is being looked after. Of course, the awareness of civilization and intellectual light is also on the rise among other professions.

However, the more intellectual the work, the more direct the way in which cultural progress takes place. The intelligentsia, understood in this way, is to some extent a separate social class" (Moszczeńska 1906). The understanding of the intelligentsia and its social mission was highly idealistic, obviously, and therefore difficult to fulfill. On the other hand, Jerzy Jedlicki underlined that "the social form of the intelligentsia's existence is its milieu. (...) The intelligentsia, wherever they were found, even in small numbers, created a milieu: local, professional or academic, in a word, a social milieu of their own choice" (Jedlicki 2009, 19). 
The question is, however, how separate this specific strata was from the other spheres of urban society? Obviously, the intelligentsia generally was a typically urban strata, strongly connected with the metropolitan social environment and the associated lifestyle which a capital city could offer. Being a part of the intelligentsia meant being an active member of the new urban society, whose individual moral stance and unswerving service set the targets to which the whole nation should aspire.

However, even if the intelligentsia itself was an urban group of the population, interested in urban topics and binding their future with cities, the mentality of this group was still closer to the old nobility, the "szlachta," then to Western bourgeoisie (Zarycki and Smoczyński 2017). The reason was quite obvious-Polish intelligentsia was formed mainly by the outclassed nobility, while in the West creation of the bourgeoisie was mainly a result of the rising aspirations of burghers (Janowski 2014).

In pre-modern Poland, urbanism generally had a low status in the value system of the nation's intellectual elites (Kopczyńska-Jaworska 1993). For instance, the so-called "Warsaw positivists," the leading intellectual movement in the Kingdom of Poland in the second half of the nineteenth century, were strong advocates of the idea of progress and westernization of Poland. Nevertheless, they distanced themselves from the mieszczanistwo, dominated by Germans and Jews, and believed that the processes of assimilation and economic development would Polonize these groups in the future (Jedlicki 1999). They believed that next to Jewish or German Kronenbergs, Lilpops or Grohmans, soon Polish Wokulscy, and Borowieccy would appear. However, they had neither strength nor means to make this dream come true. As a result, if the affluent German or Jewish bourgeois families represented by the first set of names in the Kingdom of Poland were tangible, their Polish counterparts remained only a literally fiction created by famous novelists Bolesław Prus and Władyslaw Reymont, respectively.

The younger Warsaw's intellectuals were also very sceptical about burghers as possible supporters of the national movement (Śmiechowski 2018). In 1904 Przeglad Wszechpolski, the most important journal of the National Democratic Party, stressed:

Our mieszczansstwo have never proved that they have political passion and tendencies. [They never proved] that by using its ambition and civic virtues they reach beyond the narrowly understood professional interests, speculations and markets. From the political point of view, they have neither attitudes nor intentions, plans or purposes. The question inevitably arises: why? Why do the wealthiest strata in our country not show predispositions based on their social status?

Obviously, the intelligentsia generally was a typically urban strata, strongly connected with the metropolitan social environment and the associated lifestyle which a capital city could offer. 
Why do our bourgeoisie not follow their Western European and American counterparts, who achieved political hegemony with steady hands? The most probable answer is that our wealthy and even wealthier urbanites are, including even those of Warsaw, not national in their blood and spirit. (Wolomirski 1904)

However, the real impact of the ideas and concepts created by the intelligentsia were limited by the position of this group in the urban social hierarchy. Serving as the vanguard of society, or fulfilling the public mission that a real member of the intelligentsia was expected to do was much easier in Warsaw than in any other place in the Kingdom of Poland. Warsaw, which had 700,000 inhabitants in 1900, was a real metropolis, and only this huge cultural center, unlike the provincial cities and small towns, offered suitable conditions (Corrsin 1989).

Newspapers from Warsaw often criticized professionals who lived in the province and their "provincial lethargy" became a permanent topic of complaints. There was only one city in Russian Poland where the Warsaw's point of view was challenged. This was the industrial city of Łódź, the second biggest city in the Kingdom of Poland, with over 300,000 inhabitants in 1897, located just 100 kilometers west from Warsaw. Flourished during the nineteenth century, Łódź was the vanguard of modernity in the Polish (if not Eastern European) context (Zysiak et al. 2018, 18-24).

The public opinion of Łódź offered alternative perspective on the modern urbanity, which often went against the grain. Łódź was a place where the process of strengthening the Polish influences took place in real life, but in different form that the Polish intelligentsia had imagined (Śmiechowski 2020a). This industrial hub was a conglomerate of three nations -Germans, Jews and Poles, with Germans building the most affluent and long most influential strata of the urban society. Poles in turn, were the poorest group, and remained simple workers, often with rural origins.

However, in the 1880s Poles made up the largest section of the population while the Germans were the third-largest one. The cultural and economic hegemony of the Germans was considered to be a serious threat in Warsaw. In the 1880s and 1890s Polish public opinion thought of Łódź as an "alien city," where workers were exposed to foreign influences and cosmopolitanism (both exaggerated in Polish public discourse at the time). Indeed, the German community in Łódź was well organized and little interested in close relationships with Polish elites.

It may therefore be concluded (Śmiechowski 2012, 94-104; Marzec and Zysiak 2016), that when mapping the national structure on the social stratification, the German population constituted a Bildungsbür- 
gertum, typical for German-speaking countries, and characterized by a hierarchic model of social bonds and common respect for the richest members of community. Contrary to popular idealistic opinions, so-called "Lodzrmenschen" had very limited relations with the Polish elites until the beginning of the twentieth century (Źarnowska 2004).

Before the 1905 Revolution local Polish journalists from Łódź tried to develop the concept of the "provincial intelligentsia," which was generally a variant of social identity available for educated people living outside Warsaw (Śmiechowski 2014a, 131-44). Local activists believed that they had many specific missions and tasks to do while compared to the commercial elites of society: organizing, developing and enlivening local cultural life with a very little hope of replacing the local bourgeois elites.

However, even for them political outbreak was necessary to initiate action (Iwańska 2015). The project of citizenship-building among the Polish elites of Łódź was intended to make them capable of competing with groups perceived as foreign. For instance, German and Jewish bourgeois elites were compared to migrating birds which fly from one country to another: "I hope," the author stated, "that thousands of these bird-citizens approach citizenship duties honestly and seriously" ("Mały Felieton. Powrót Ptactwa.” 1906).

After local industrial bourgeoisie started the great lockout in 1907 and thousands of workers were left starving in the middle of winter, the intelligentsia of Łódź lost any hopes for the cooperation with the factory owners. At the same time, intelligentsia was more and more alienated from the workers, engaged in sectarian quarrels and street violence. In the reality of Łódź, local intelligentsia still had to conceptualize itself. This inconvenient situation was, firstly, the result of its weakness towards to the German and Jewish bourgeoise communities, and secondly, its cultural distance to workers, who were actually excluded from any form of communication with the educated elites.

For the editorial board of Nowy Kurier Łódzki, a progressive newspaper from Łódź, post-revolutionary shock became an opportunity to rethink the relations between the intelligentsia and other social strata. Inasmuch as the hopes for a collaboration with the bourgeoisie had failed, it became obvious that the intelligentsia could not be a real social power without the support of workers.

The question was raised in an article from 1912:

How many times is it seen that the ordinary craftsmen or worker can be a person with a vital and open mind, critical and working on further self-education. A smart person with real intelligence and knowledge of his own can be much 
clever than the quasi-intelligent in a fashionable frock coat. It is necessary to redefine the intelligentsia. External features under any circumstances cannot be an index of intelligentsia. (“Inteligencja umysłowa." 1911)

One year later the newspaper categorically stated that:

it is not the formal position but the moral values of the individual that can be the measure of being a member of the intelligentsia. (...) What is a doctor, attorney, professor or writer if he does not understand the life of his society and does not understand what society currently thinks? Is this the intelligentsia of the nation? No, people like this are mental simpletons. ("Kto jest inteligentem?" 1912)

There is no doubt that the new concept of intelligence was associated more with the sphere of morality than with formal framework of belonging like education or profession. On the other hand, searching for the cooperation with open-minded workers or craftsmen testified to the practical problems with implementing the ideal of a socially involved intelligentsia in the industrial society. What should be stressed here, Łódźs approach to this topic remained specific until the city become big academic center after 1945 (Śmiechowski 2020a, 156-9).

\section{Reconceptualizing of Urbanism}

Similar dilemmas were not so widespread in Warsaw, where shortly after the Revolution Polish intelligentsia has become ready to dream about its political hegemony over others groups of the urban society. I assume, therefore, that the idea of a Polish mieszczanstwo, developed after the 1905 Revolution, was indeed the last step in the transformation of the intelligentsia from a theoretical concept that had to be still adapted in real life, to the leading actor of the modern urban society, aspiring to act as the dominant power.

To answer how it happened, some analyze of the psychological basis of changes in the perception of cities after 1905 is needed. Firstly, we must remember that Polish intellectual elites, especially liberal elites, never gave up the dream of Polonization of the cities. The intelligentsia, being itself a creation of factors like the outclassing of szlachta, abolishment of serfdom, rapid urbanization and social changes linked with it, observed with fascination intermingled with fear how in the rural landscape of the Kingdom industrial giants like Łódź or Żyrardów grew. 
Secondly, the rise of the intelligentsia occurred in the same time when Warsaw turned from the capital of a fallen empire into an European city on imperial periphery (Porter 2000, 76-8). Educated elites of the Polish urban society could not accept the fact that they did not have the decisive role in the Polish capital because of their own weakness and predicaments of the Russian rule. While the government was seen as a foreign, imposed enemy, Jews were perceived as a malevolent force trying to weaken Polishness from within (Weeks 2006, 152-6).

However, until the urban question in the Kingdom of Poland became a political issue, the predominance of Jews among the population of the towns was generally accepted. In 1905 Bolesław Prus, alarmed by the fledgling Zionism, wrote: "for us Poles, Jews are not only our closest neighbours, but they have become a very important social organ, the mieszczaństwo" (Prus 1905, 783). As mentioned above, the 1905 Revolution changed the Polish public sphere deeply. The intensity of proletarian riots, not free of aggression and brutality stirred up critique. As well popular agitation on huge mass meetings were considered too chaotic, uncultured if not dangerous by many elite actors. As Grzegorz Krzywiec argued:

The social strata on which the pre-revolutionary social order was based, as well as a large number of the intellectual elites considered the revolution to be a historical scandal and act of violence against traditional values. (...) The fear or, more precisely, awe of uncontrolled masses became the motif which, after all, linked the dominant part of the public opinion together. (Krzywiec 2017, 24-5)

These changes had an understandable psychological basis.

During the first months, Krzywiec argues, the revolution showed and actualized two, perhaps most ominous, fears of the social establishment, middle classes, bourgeoisie and burghers about modernity: uncontrollable masses on the streets as well as sudden and unexpected deaths, rapes, terror and violence involving revolutionists.

Fear was even stronger than the real scale of this events. Under this circumstances, the nationalist political camp, National Democracy successfully remodeled its political strategy (Marzec 2016). This transformation was easily seen in the endecja's political magazine, Przeglad Narodowy. Leaders of National Democracy admitted that:

there was a moment when we were all convinced that all our working people were strangers to national matters and were committed solely to class slogans. 
Fortunately, this conviction had to be altered due to the rapidly developing national workers' movement and the cultural progress among an important section of workers. It should be stressed that cultural and educational activities among this sphere reached impressive results very quickly. This fact has great importance for predictions about our cultural and national future. ("Przyczynki do bilansu sił narodowych w Królestwie." 1908, 76)

In the same article the bourgeoisie was described in the blackest colors. The national democrats had no doubts that "one of the historical failures of Poland was the lack of the native bourgeoisie," who could be a patron of the national democratic movement. This kind of splendid isolation of the bourgeoisie was also the crucial problem for the Polish urban intelligentsia, consisted of "medical doctors, lawyers and factory clerks" who were doing "diligent and fruitful work on the national culture in the most difficult conditions" ("Przyczynki do bilansu sił narodowych w Królestwie.” 1908, 64-5). In a result, cities, previously considered lost, suddenly became sites of political expansion.

In 1909, five years after the initial announcement, legislative procedures with the project of urban reform in the Kingdom of Poland were finally initiated by the government. All voters were to be divided on ethnic groups which could elect limited number of councillors. Tsarist government wanted to limit the number of Jewish councillors to $10 \%$ in the biggest cities and $25 \%$ in the smaller ones, where Jews were generally a majority of inhabitants.

This anti-Semitic law initially surprised the public opinion in the Kingdom of Poland. In the so-called "Polish" draft of the future urban reform, prepared in 1906 by well-known lawyer Adolf Suligowski, voting system was based on economic, not ethnic division of urban population (Śmiechowski 2014b). Idea of curial voting was introduced mainly to ensure the influence of the Russian, rather than to play Poles and Jews against each other. However, new situation quickly turned into the ethnic conflict, what was a challenge for different Polish political groups.

The question was-should the Poles support limitations for Jews or stay with the principles of democracy? (Weeks 1994; 2008, 152-71). What interest me here is how the mieszczaństwo has been revaluated in these discussions. To follow this process, I will analyse here some selected, but the most representative examples.

First of all, as a consequence of the government project, the size of Jewish population in Russian Poland became an object of interests in the daily press. In 1908 some Gtos Warszawski published some interesting opinion of "well-known progressive writer," who argued: 
We are the minority in many cities where Polish blood was shed in history and we will cease to be hosts there if the voting laws will be equal for all. Let us take, for example, Lublin, the old Polish city, occupying the third place in the Kingdom of Poland, which has so many threads connected with the history of the Polish nation-Jews have the overwhelming majority there. With equal rights, the Jews themselves would be elected as councillors and a Jew would be the mayor of the city. (...) Most importantly, Jewish victory would also be possible even in Częstochowa. Częstochowa is our Jerusalem, where the greatest holiness of the Polish nation is located. (...) How could we agree that Jews will be hosts of that city because of the principles of equality? ("Samorząd a Żydzi." 1908)

In my opinion, this quote perfectly reflects what was happened in minds of the Kingdom's Polish intelligentsia at that time. The fact that Poles were not the majority in cities was of course well known to the participants of the debates and could not come as a surprise to anyone who seriously wanted to talk about urban issues of the Kingdom of Poland. Nevertheless, in statements such as the one quoted above, there is a certain hint of disbelief that a scenario in which Poles would lose control over Polish cities as a result of the elections would indeed be possible.

For instance, Kurier Warszawski, published an analysis of data on the structure of estate possession in the Kingdom's cities, prepared during the parliamentary debate over the local government. The author wrote with an unmasking tone:

it can be easily said that we do not know our country. This ignorance is noticeable in any possible moment. (...) Cities, that we believe to be ours, to be our century-old heritage; cities, for which we bring our monuments and mementos, are only half-way our possession, and there are such cases where our possession is only a percentile. ("Stan posiadania miast naszych." 1910)

"The inner enemy" created on the pages of newspapers, turned out to be the strongest exactly where the biggest damage could be done-in big cities and national industry centers.

The answer to the "Jewish threat" could be only the Polonization of the cities. This could only be done, however, by systematic work on the Polish weaknesses. Liberal journalist Wincenty Rzymowski did not have any doubts that:

the 19th century passed by, marked by the hegemony of the middle-class. (...) The city humiliated the country. The mieszczanistwo became the master of the 19th century." Meanwhile, "the Polish nation did not own the cities. (...) During

The fact that Poles were not the majority in cities was of course well known to the participants of the debates and could not come as a surprise to anyone who seriously wanted to talk about urban issues of the Kingdom of Poland. 
the 19th century the country, due to political storms, ended torn, but the city did not rise; the nobility was pushed away from forging culture. However, the middle-class did not take over in the national work, because in the past, we did not have the intelligentsia, in the past foreign elements thrived, strange to our culture and nationality.

Due to the fiasco of the assimilation idea there could only be one answer:

We must raise a huge national wave and direct it towards the city. The country must go to conquer trade and industry. This levy in mass happened in Western Europe 500 years ago; in Poland it must happen now: otherwise-the country, cut from the city, will go deaf, become infirm, will seal up and die. Getting the cities for the Polish culture is a life necessity for our nation. It is to be or not to be for our nation. (Rzymowski 1912, 3-4)

\section{Fighting for the Right of the City}

There is no need to remind what happened to Polish-Jewish relations just before the First World War (Weeks 1994; 2008, 152-70; Zieliński 2010, 65-99). If the local government debate triggered the intensification of anti-Semitic sentiments, the elections in 1912 caused an open conflict between Poles and Jews. In all elections in Russian Poland after 1905 system of curiae, which guaranteed majority for the Polish right-wing and conservatives parties, was implemented.

However, in 1912 electoral law was changed in a way which ended the political hegemony of National Democracy. After Dmowski's resignation historian Jan Kucharzewski was appointed as a moderate candidate of Polish national political parties ("Koncentracja Narodowa") from Warsaw. However, Kucharzewski refused to promise that if elected, he would vote against the Jewish limitations in the future local government.

As a result, Jews decided to select a socialist Eugeniusz Jagiełło, who as a Duma member collaborated with the Russian left not the Polish Circle. For the Polish such results of the 1912 Duma elections were shocking. Even centrist started to believe that Dmowski was right and Jews were "inner enemies" who just wanted to harm Polish political interests (Weeks 2006, 163-9). The old idea of assimilation became dead and National Democracy triumphed even if it lost prestigious seat in the parliament. The dream about "truly Polish" middle-classes has changed from the nightmare into the actual political 
demand of the majority of opinion-makers.

However, the concrete visions of how the Polonization would happen in practice were rather foggy. Even in the pages of the right-wing Gazeta Warszawska it was only believed that the Polish intelligentsia should emerge not from educated individuals, but from the Polish folk-however, there was little hope for quick realization of these plans. As one of the journalists wrote:

I believe that the only way to the creation of a strong and industrious middle class in the city is the revolution from the very bottom, awaking the industrialism in the folk stratum-lower middle class and peasant. These stratums, as those pursuing fortune, are frugal, rough, and even-ruthless. These are the virtues that are necessary to withstand the competition with the Jews who overtook the petty trade and crafts. (“O polski stan średni." 1912)

One can say that the whole concept of the "Polish mieszczaństwo" was just an element of the ideology of the National Democrats, the direct consequence of their antisemitism and dreams about the "national expansion" (Porter 2000, 219-31). Obviously, such an opinion would be correct. But it is worth to ask why the anti-Semitic seeds directed by National Democracy found such a fertile ground. In my opinion, an answer could be as follows: the idea of the Polonization of cities would not have found wide hearing if had not met the desires of the urban intelligentsia, dreaming about its own rules over Warsaw and other urban settlements.

Ideologies, especially the expansive ones, do not achieve mass support if conditions are not suitable. Meanwhile, after the 1905 Revolution important part of the "progressives" wanted to participate as actors in a play written by Roman Dmowski and his circle. The one who voiced his opinion regarding the boycott was, among others, Jerzy Kurnatowski, who willingly joined the infamous "antisemitic conduct" of the progressivists after Andrzej Niemojewski and Iza Moszczeńska. The reasoning of Kurnatowski was rather simple. He wrote:

The situation today appears as follows: our cities are in the hands of Jews and Germans who are not Polonizing themselves. Our country sends yearly emigration (...) of over a million people. At the same time, we have money. The Polish middle-class does not have much, but peasants have it in credit unions, and so does the aristocracy in covered bonds and other calm assets.

What was to be done with all this capital according to Kurnatowski? 
There is a need for people who, with Polish money (that there is), would create a Polish industry and trade in such a way that would enable giving more work to Polish workers and stop the emigration. (Kurnatowski 1913)

Of course, if it were so easy, the Kingdom of Poland in 1913 would have already been filled with industrial and trade achievements of numerous Polish industrialists. This, however, did not happen. A seemingly natural, logical consequence that Kurnatowski found, was the mass emigration of Jews from the Kingdom.

The most reasonable answer-he pointed-that the Jews could give to the Polish society is, on one hand intensive and final Polonization of these Jewish elements that wish to remain in this country, and facilitating the emigration to wide masses of the Jewish mieszczaństwo and cottage workers. (...) And this decision Poles must not only make but also perform if they want to exist at all. (Kurnatowski 1913)

It needs justice that boycott action conducted by endecja after the 1912 elections gained radical critics as well. Ludwik Krzywicki, the prominent Marxian intellectualist, accurately exposed its weakness when writing for Nowa Gazeta:

Polish trade is still at the stage of its creation. This hatching happened when capitalism started issuing higher forms of commercial brokerage, on one hand huge warehouses of retail sales, and on the other hand, food cooperatives. It is worth remembering when talking about Polonization of the cities. (Krzywicki 1912)

After 1912 the logic based on strong antagonization of the Polish majority and the Jewish population reached far beyond acceptable frames of public debate. At the same time, the anti-Semitic spectacle by National Demoracy, took up so easily by the commercial, apolitical press like Kurier Warszawski and others. Robotnik, the official magazine of Polish Socialistic Party commented:

What Dwugroszówka [officially Gazeta Poranna 2 Grosze, an aggressive anti-Semitic daily published from 1912] in its unbelievable rudeness expressed without any reserve, is in a more general and delicate way repeated by the whole bourgeois press, conservative and the so-called progressive alike. The future of the Polish nation is not with the fight with the tsarism but with the fight with Jews-this is the motto of the whole Polish mieszczañstwo. ("Kronika." 1913) 
Although Polish socialists and leftist intellectuals accurately scored all shallows of the nationalist fever, they did not have a language that could convince the majority of the intelligentsia. Like their Russian counterparts, they overestimated the importance of the working class in society. As Robert Edelman argued: "Russian Marxists had fixed on the urban proletariat as the social force that would lead an eventual socialist revolution. Yet the working class of the cities was still a small fraction of the entire population. To be politically effective, workers had to seek allies" (Edelman 1987, 8). For socialists, the successful revolution would overthrow all urban elites including the bourgeoisie and middle-class and make a workers' proletarian government possible with the necessary support of the intelligentsia. An alliance with the mieszczanistwo was out of the question. The Polish Socialist Party body commented on the boycott as follows:

The fact that this advertising magazine of a Polish shop assistants could, without its incomparable coarseness and stupidity, obtain such a large influence among the mieszczanstwo, that even these groups and bourgeois bodies that initially opposed to it, yielded, proves how low the Polish mieszczaństwo fell, how it is retarded, how it debased itself. ("Kronika." 1913)

\section{Urbanization of Minds}

Neil Davidson offers an interesting distinction between political and social revolutions. As he argues:

political revolution does no more than sanction a socio-economic situation that has been able to impose itself at least in part upon the economic reality. Such a revolution forcibly replaces the old legal order, now felt to be "unjust" by the new "right," "just" law. There is no radical reorganization of the social environment. (...) Social revolutions, however, are concerned precisely to change this environment. (Davidson 2012, 500)

In a similar vein, Piotr Kuligowski noted that "conceptual change is therefore never a purely theoretical issue, but it involves significant phenomena from the political space. Language changes interfere with transformations taking place in the socio-economic context" (Kuligowski 2017, 163).

Although the Polish-Jewish conflict intensified before World War I undoubtedly was grounded in traditional popular antisemitism, supported by the Catholic church, it also had a solid foundation in the very 
modern changes in social relations in Russian Poland. (Blobaum 2001; 2015; Zieliński 2010) It seems, however, that ethnicizing the discourse and its infamous consequences bore witness not only to the degeneration of the Polish mieszczaństwo, but also to the entrance of the Polish intelligentsia into a new phase.

The city, from a liveable space, became for this group a political stake or domain where moral "right" to rule could be executed, and hence an area for which one needs to fight. To apply this transformation in politics, some important reconceptualization of the urban society had to be done. After the 1905 Revolution, the intelligentsia and mieszczaństwo did not only redefine themselves, but also the expected relations between these groups in the envisioned modernization of Poland were rearranged.

How far did this program reach? As it seems, it could be successful in Warsaw where there was quite a broad presence of Polish petty bourgeoisie. However, in Łódź, not far away, it was unthinkable to effectively take "the right of urban citizenship" away from the "foreigners." The response to the nationalistic turn that happened in the Kingdom after 1905 was in Łódź rather late and more toned down than in Warsaw where the aggressive antisemitism oozing from the pages of the capital's Dwugroszówka hold sway (Zysiak et al. 2018, 98). On the other hand, in the provinces where the Polish mieszczanstwo was even weaker than in Warsaw or Łódź, and Jews were majority of the population, like in Lublin, there were no circles capable of opposing the growing hatred between Poles and Jews.

Even though the ethnic conflict in the Kingdom became very aggressive, it should be considered the outcome of modernity rather than its reverse. Such a tension was by any standard a Polish specificity-after all the example was coming even from Vienna, where anti-Semitic urban politics loomed large (Boyer 1981). The core of this ethnic conflict in the cities of the Polish Kingdom were tensions between fast modernizing urban communities-Polish and Jewish. Both of these groups-Poles not agreeing to the Jewish majority in the future local-government and Jews not accepting attempts of sidelining them-were well aware that success or failure of their modernization would be defined in the cities (Ury 2012). For the Jewish urban dwellers, the city was an everlasting, obvious component of their identity, but for the Poles, in turn, including the urban perspective in their own nationalistic project was a significant novum.

It is worth noting that it was on the local level where the shape of citizenship was decided-nations are not divided into local communities, but rather consist of them. Belonging to the community of a given 
region and of a particular city implies the identification with the nation and not the other way round (Lowndes 1995, 162). Thus, when the Polish public opinion grasped its own weakness and even "alienation" from the cities, not only the poison of antisemitism was released, but also strives to change their own status boosted. The city became a crucial forum of politics, where "to be or not to be" of the Poles was played, just like in the case of other nations in East-Central Europe. Idea of modern Polishness was to be defined not in the countryside, but on the streets of Polish towns. This change is perfectly pictured by a quotation from the early 1914. Tygodnik Ilustrowany, the same magazine where Prus just a decade earlier identified the Jews with as the "our mieszczaństwo," stated in the editorial:

There is no Pole who would not dream a beautiful dream of the future: a country cut through with a network of solid roads, iron railways, canals linking navigable rivers. A country smiling with prosperity and culture, combining together a high level of farming with a high level of industry. A country covered with schools, hospitals, functioning from the top to bottom like a fit, well-composed organism. A country of affluent villages with brick houses and farmsteads, a country of white cities, flooded with the greenery of gardens, happy and pleasant for the eye. ("Miasteczko." 1914)

What was the paradox of the situation, in Russian Poland it was not possible to introduce a local government that would fulfil Polish national aspirations? Moreover, Poles themselves were also not ready for full democratization of the urban political life (Śmiechowski 2014b). Without the influence on urban politics and economy, creating of the domestic mieszczaństwo could only be a utopia. So, it was obvious that cities in Russian Poland would remain as they were so far: multicultural and religiously diverse, with a significant influence of the Jewish and German communities.

However, despite these circumstances there is no doubt that cities took its rightful place in the value system of the Polish intelligentsia before the Great War. The urban intelligentsia of the Kingdom of Poland believed that it could exercise power over the cities-become the mieszczaństwo by necessity.

Although the Polish mieszczanistwo had to remain only a dream in the forthcoming decades, this concept had an undeniable emancipatory dimension. Riga claims that in late imperial Russia "class (economy) and status (politics) were both autocratically organized around ethnicity" and "living in the empire's borderlands, multiethnic urbanism, and quasi- or problematic assimilationism" were "a common dimension of 
The class-universalism and aggressive nationalism become the alternatives for the Polish intelligentsia. Both took the city in the center of

the imagined future, breaking with traditional concept of Polishness embedded in an agrarian society and the szlachta's country house as a center of the universe. experience" among the marginalized groups (2008, 653).

The class-universalism and aggressive nationalism become the alternatives for the Polish intelligentsia. Both took the city in the center of the imagined future, breaking with traditional concept of Polishness embedded in an agrarian society and the szlachta's country house as a center of the universe. Despite its agrarian past, Poland had to become urban if it wanted to be modern and the intelligentsia had to become urban if wanted to create real Polish mieszczanistwo in the future. In Polish case, those liberation of minds from existing patterns had significant long-term consequences.

\section{References}

Blobaum, Robert E. 1995. Rewolucja: Russian Poland, 1904-1907. Ithaca-London: Cornell University Press.

- 2001. "The Politics of Antisemitism in Fin-de-Siècle Warsaw." The Journal of Modern History 73(2): 275-306. https://doi. org/10.1086/321025.

- 2015. "A Warsaw Story: Polish-Jewish Relation during the First World War." In Warsaw. The Jewish Metropolis: Essays in Honor of the 75th Birthday of Professor Antony Polonsky, edited by Glenn Dynner and François Guesnet, 271-98. Leiden-Boston: Brill.

Boyer, John W. 1981. Political Radicalism in Late Imperial Vienna: Origins of the Christian Social Movement, 1848-1897. Chicago-London: University of Chicago Press.

Brower, Daniel R. 1986. "Urban Revolution in the Late Russian Empire." In The City in Late Imperial Russia, edited by Michael F. Hamm, 319-55. Bloomington: Indiana University Press.

Corrsin, Stephen D. 1989. Warsaw Before the First World War: Poles and Jews in the Third City of the Russian Empire 1880-1914. Boulder-New York: East European Monographs, Columbia University Press.

Davidson, Neil. 2012. How Revolutionary Were The Bourgeois Revolutions? Chicago: Haymarket Books.

Edelman, Robert. 1987. Proletarian Peasants. The Revolution of 1905 in Russia's Southwest. Ithaca-London: Cornell University Press.

Gellner, Ernest. 1970. "Concepts and Society." In Sociological Theory and Philosophical Analysis, edited by Dorothy Mary Emmet and Alasdair C. McIntyre, 115-49. London: Palgrave Macmillan.

"Inteligencja umysłowa." 1911. Nowy Kurier Łódzki, August.

Iwańska, Marzena. 2015. "Inteligencja i rewolucja w Łodzi w latach 
1905-1907." Studia z Historii Społeczno-Gospodarczej XIX i XX Wieku 15: 65-98. https://doi.org/10.18778/2080-8313.15.05.

Janowski, Maciej. 2014. Birth of the Intelligentsia - 1750-1831, vol. 1 of A History of the Polish Intelligentsia - Part I, edited by Jerzy Jedlicki. Translated by Tristan Korecki. Frankfurt am Main: Peter Lang. Jedlicki, Jerzy. 1999. A Suburb of Europe: Nineteenth-Century Polish Approaches to Western Civilization. Budapest: Central European University Press.

___ 2009. "Problems with the Intelligentsia." Translated by Agnieszka Kreczmar. Acta Poloniae Historica 100: 15-30.

Katz, Steven T., ed. 2007. The Shtetl: New Evaluations. New York-London: New York University Press.

Kmiecik, Zenon. 1980. Prasa polska w rewolucji 1905-1907. Warszawa: Państwowe Wydawnictwo Naukowe.

Kochanowicz, Jacek. 2006. Backwardness and Modernization: Poland and Eastern Europe in the 16th-20th Centuries. Aldershot: Ashgate Variorum.

Kopczyńska-Jaworska, Bronisława. 1993. "Miasto i miejskość w systemie wartości Polaków.” In Miasto i kultura polska doby przemysłowej. [3] Wartości, edited by Hanna Imbs, 99-121. Wrocław: Zakład Narodowy im. Ossolińskich.

Koshman, Lidiia Vasil'evna. 2016. "The Meshchanstvo in Nineteenth-Century Russia.” Russian Studies in History 55(2): 97-125. https:// doi.org/10.1080/10611983.2016.1200353.

Kożuchowski, Adam. 2020. "A Demonic Chrysalis: The Concept of Bourgeoisie in Poland." Acta Poloniae Historica 122: 79-107. https:// doi.org/10.12775/APH.2020.122.04.

"Kronika." 1913. Robotnik 236(9), April.

Krzywicki, Ludwik. 1912. "Sprawa żydowska." Nowa Gazeta 597, December.

Krzywiec, Grzegorz. 2017. Polska bez Żydów. Studia z dziejów idei, wyobrażen i praktyk antysemickich na ziemiach polskich poczatku XX wieku (1905-1914). Warszawa: Instytut Historii PAN.

“Kto jest inteligentem?” 1912. Nowy Kurier Eódzki, August.

Kuligowski, Piotr. 2017. "Ouvriers, proletarjat czy stan czwarty? Konceptualizacja klasy robotniczej w kręgach polskiej lewicy (1832-1892)." Praktyka Teoretyczna 23(1): 160-94. https://doi. org/10.14746/prt.2017.1.6.

Kurnatowski, Jerzy. 1913. "Polskie mieszczaństwo.” Kurier Warszawski 14, January.

Lowndes, Vivien. 1995. “Citizenship and Urban Politics." In Theories 
of Urban Politics, edited by David Judge, Gerry Stoker and Harold Wolman, 160-80. London-Thousand Oaks-New Dehli: Sage Publications.

"Mały Felieton. Powrót Ptactwa." 1906. Kurier Łódzki 210.

Marzec, Wiktor. 2016. "What Bears Witness of the Failed Revolution? The Rise of Political Antisemitism during the 1905-1907 Revolution in the Kingdom of Poland." East European Politics \& Societies 30(1): 189-213. https://doi.org/10.1177/0888325415581896.

Marzec, Wiktor, and Kamil Śmiechowski. 2016. "Pathogenesis of the Polish Public Sphere. The Intelligentsia and Popular Unrest during and after the 1905 Revolution." Polish Sociological Review 4: 437-57.

Marzec, Wiktor, and Risto Turunen. 2018. "Socialisms in the Tsarist Borderlands: Poland and Finland in a Contrastive Comparison, 1830-1907." Contributions to the History of Concepts 13(1): 22-50. https://doi.org/10.3167/choc.2018.130103.

Marzec, Wiktor, and Agata Zysiak. 2016. “»Journalists Discovered Łódź like Columbus. "Orientalizing Capitalism in the Late Nineteenthand Early Twentieth-Century Polish Modernization Debates." Canadian-American Slavic Studies 50(2): 213-43. https://doi. org/10.1163/22102396-05002007.

"Miasteczko." 1914. Tygodnik Ilustrowany 13: 250.

Moszczeńska, Iza. 1906. "Klasy społeczne i inteligencja." Ludzkość, October. "O polski stan średni." 1912. Gazeta Warszawska 33, February.

Pipes, Richard. 1960. "The Historical Evolution of the Russian Intelligentsia.” Daedalus 89(3): 487-502. Accessed March 29, 2021. https://www.jstor.org/stable/20026594.

Porter, Brian. 2000. When Nationalism Began to Hate: Imagining Modern Politics in Nineteenth-Century Poland. New York: Oxford University Press.

Prus, Bolesław. 1905. "Kwestia żydowska u nas.” Tygodnik Ilustrowany 42: 783-84.

"Przyczynki do bilansu sił narodowych w Królestwie." 1908. Przeglad Narodowy 1: 60-82.

Riga, Liliana. 2008. "The Ethnic Roots of Class Universalism: Rethinking the 'Russian' Revolutionary Elite." American Journal of Sociology 114(3): 649-705. https://doi.org/10.1086/592862.

Rzymowski, Wincenty. 1912. "Być albo nie być.” Prawda: Tygodnik Polityczny, Spoteczny i Literacki 48: 1-4.

Samuś, Paweł. 2013. Wasza kartka wyborcza jest silniejsza niż karabin, niż armata...: Z dziejów kultury politycznej na ziemiach polskich pod zaborami. Łódź: Wydawnictwo Uniwersytetu Łódzkiego. 
Sdvižkov, Denis. 2006. Das Zeitalter Der Intelligenz: Zur Vergleichenden Geschichte Der Gebildeten in Europa Bis Zum Ersten Weltkrieg. Göttingen: Vandenhoeck \& Ruprecht.

Śmiechowski, Kamil. 2012. Z perspektywy stolicy. Łódź okiem warszawskich tygodników społeczno-kulturalnych (1881-1905). Łódź: Wydawnictwo Ibidem.

. 2014a. Łódzka wizja postępu: Oblicze społeczno-ideowe "Gońca Łódzkiego", "Kuriera Łódzkiego" i "Nowego Kuriera Łódzkiego" w latach 1898-1914. Łódź: Dom Wydawniczy Księży Młyn.

. 2014b. "Searching for the Better City: Urban Discourse during the Revolution of 1905 in the Kingdom of Poland." Praktyka Teoretyczna 13(3). https://doi.org/10.14746/pt.2014.3.4.

. 2018. "Endeckie postrzeganie miasta: Ewolucja tematyki miejskiej na łamach 'Przeglądu Wszechpolskiego' i 'Przeglądu Narodowego'.” Studia Podlaskie 26: 7-26. https://doi.org/10.15290/ sp.2018.26.01.

- 2020a. "How Do Local Conditions Inform Socio-Political Language? The Concept of 'Intelligentsia' in Łódź Press Before the Mid-Twentieth Century.” Acta Poloniae Historica 122: 135-63. https://doi.org/10.12775/APH.2020.122.06.

. 2020b. Kwestie miejskie. Dyskusja o problemach i przyszłości miast w Królestwie Polskim 1905-1915. Łódź: Wydawnictwo Uniwersytetu Łódzkiego.

“Stan posiadania miast naszych.” 1910. Kurier Warszawski, September. Tréncsenyi, Balázs, Maciej Janowski, Monika Baár, Maria Falina, and Michal Kopeček. 2016. A History of Modern Political Thought in East Central Europe: Volume I: Negotiating Modernity in the 'Long Nineteenth Century.' New York: Oxford University Press.

Ury, Scott. 2012. Barricades and Banners: The Revolution of 1905 and the Transformation of Warsaw Jewry. Stanford, Ca: Stanford University Press.

Walicki, Andrzej. 2005. "Polish Conceptions of the Intelligentsia and Its Calling." In Words, Deeds and Values: The Intelligentsias in Russia and Poland during the Nineteenth and Twentieth Centuries, edited by Fiona Björling and Alexander Pererwetoff-Morath, 22: 1-12. Lund: Department of East and Central European Studies.

Weeks, Theodore R. 1994. "Nationality and Municipality: Reforming City Government in the Kingdom of Poland, 1904-1915.” Russian History 1: 23-47.

. 2006. From Assimilation to Antisemitism. The "Jewish Question" in Poland, 1850-1914. DeKalb: Northern Illinois University Press. 
2008. Nation and State in Late Imperial Russia: Nationalism and Russification on the Western Frontier, 1863-1914. DeKalb: Northern Illinois University Press.

Wolomirski, Stefan. 1904. "Przewodnictwo mieszczańskie.” Przegląd Wszechpolski 10: 493-508.

Żarnowska, Anna. 2004. "Próby kształtowania autowizerunku w wielkomiejskiej opinii publicznej. Przedsiębiorcy Warszawy i Łodzi na przełomie XIX i XX w.” Przeglad Historyczny XCV: 195-211.

Zarycki, Tomasz, and Rafał Smoczyński. 2017. Totem inteligencki: arystokracja, szlachta i ziemiaństwo w polskiej przestrzeni społecznej. Warszawa: Wydawnictwo Naukowe Scholar.

Zieliński, Konrad. 2010. Stosunki polsko-żydowskie na ziemiach Królestwa Polskiego w czasie pierwszej wojny światowej. Lublin: Wydawnictwo Uniwersytetu Marii Curie-Skłodowskiej.

Zysiak, Agata, Kamil Śmiechowski, Kamil Piskała, Wiktor Marzec, Kaja Kaźmierska, and Jacek Burski. 2018. From Cotton and Smoke: Łódź - Industrial City and Discourses of Asynchronous Modernity 1897-1994. Łódź-Kraków: Wydawnictwo Uniwersytetu Łódzkiego, Wydawnictwo Uniwersytetu Jagiellońskiego. 
KAMIL ŚMIECHOWSKI-born 1985, historian, PhD in history of Poland, assistant professor in the Institute of History, University of Łódź. His research interests are focused on urban theory, analyses of press discourse, processes of modernization in the nineteenth- and twentieth-century Poland, and history of Łódź. Recently, he has concluded a post-doc research project on urban discourse in the Kingdom of Poland at the turn of the twentieth century, supported by the National Science Center in Poland.

\section{Address:}

Instytut Historii Uniwersytetu Łódzkiego

ul. Kamińskiego 27a

90-210 Łódź

email: kamil.smiechowski@uni.lodz.pl

\section{Citation:}

Śmiechowski, Kamil. 2021. "Imagining the Urban Poland: Revolution and Reconceptualization of Urban Society in the Kingdom of Poland, 1905-1914." Praktyka Teoretyczna 1(39): 95-118.

\section{DOI: $10.14746 /$ prt2021.1.5}

Funding: This paper presents results of research project financed by the (Polish) National Science Centre contracted as UMO-2014/15/D/ HS3/00411. The article is largely based on arguments presented in my book in Polish (Śmiechowski 2020b) and other papers prepared as results of the project (Śmiechowski 2014b; 2018; 2020a).

Autor: Kamil Śmiechowski

Tytuł: Wyobrażając sobie miejską Polskę. Rewolucja i rekonceptualizacja społeczeństwa miejskiego w Królestwie Polskim (1905-1914)

Abstrakt: Celem artykułu jest analiza zmiany znaczenia pojęcia „mieszczaństwo” (w powiązaniu z takimi kategoriami, jak inteligencja czy burżuazja) w polskim dyskursie politycznym w latach 1905-1914. Hipoteza autora jest taka, że przed Wielką Wojną, w czasach rewolucji społeczno-politycznej, której areną były ulice Warszawy, Łodzi i innych miast, pojawiły się nowe sposoby konceptualizacji społeczeństwa miejskiego. Tekst omawia zatem okoliczności, które doprowadziły do uformowania się sposobów rozumienia mieszczaństwa w ramach szerszej debaty na temat samorządu miejskiego w Królestwie Polskim po rewolucji 1905 roku. Z uwagi na fakt, że w interesującym autora okresie samo miasto stało się przedmiotem rywalizacji politycznej, postulat prawa do rządzenia miastem był głośno formułowany w przestrzeni polskiej debaty publicznej. Dla narodowej demokracji była to doskonała okazja dla szerzenia retoryki antysemickiej i propagowania idei polonizacji miast 
jako celu długofalowego. Autor twierdzi jednak, że retoryka ta nie znalazłaby posłuchu, gdyby sama inteligencja nie przedefiniowała swojego stosunku do poszczególnych grup mieszkańców miast. W ten sposób mieszczaństwo, które wcześniej nie miało większego znaczenia politycznego, stało się istotnym elementem postulowanej modernizacji Polski; choć ceną za to posunięcie było rozpalenie konfliktu etnicznego. Tym samym, dla protagonistów ówczesnych sporów stało się jasne, że Polska nowoczesna to Polska zurbanizowana.

Słowa kluczowe: antysemityzm, inteligencja, Łódź, mieszczaństwo, nowoczesność, społeczeństwo miejskie, Warszawa 